\title{
POSTAWY WRAŻLIWOŚCI SPOŁECZNEJ VERSUS POSTAWY PRAGMATYCZNE I ICH OSOBOWOŚCIOWE UWARUNKOWANIA
}

\begin{abstract}
Czerniawska Mirosława, Postawy wrażliwości społecznej versus postawy pragmatyczne $i$ ich osobowościowe uwarunkowania [Social Sensitivity Attitudes versus Pragmatic Attitudes and their Personality Conditions]. Studia Edukacyjne nr 40, 2016, Poznań 2016, pp. 213-227. Adam Mickiewicz University Press. ISSN 1233-6688. DOI: 10.14746/se.2016.40.13

The main aim of this research is investigation of social sensitivity attitudes and pragmatic attitudes. It was assumed that these attitudes depend on personality traits, like empathy and Machiavellian guilt. The study group consisted of 325 students. The Empathic Understanding of Others Questionnaire (Węgliński) and Mach V Scale (Christie and Geis) were used. The attitudes were diagnosed on the basis of the set of views (two pairs of statements from the publication edited by Reykowski). The study results show that social sensitivity attitudes were accepted by students having high empathy indices. Students having high Machiavellianism show a pragmatic attitude toward life.
\end{abstract}

Key words: attitudes, social sensitivity, pragmatism, personality traits, empathy, Machiavellianism

\section{Wprowadzenie}

Zmiany ustrojowe w naszym kraju, zwłaszcza zaś przeobrażenia w sferze ekonomicznej, sprzyjają aprobacie postaw pragmatycznych, zgodnie z którymi człowiek powinien dążyć przede wszystkim do polepszenia własnej sytuacji ${ }^{1}$. Cechują się one przewagą orientacji materialistycznej i kon-

1 Bardziej wnikliwą analizę problemu Czytelnik znajdzie w publikacji: M. Czerniawska, Zmiany wartości i postaw młodzieży w okresie przeobrażeń ustrojowych - kolektywizm versus indywidualizm. Studium interdyscyplinarne, Białystok 2010. 
centracją (często nadmierną) na sukcesie finansowym² ${ }^{2}$ Pragmatyzm - obok otwartości mentalnej i samodzielności myślenia - wpisuje się w mentalność indywidualistyczną. Mentalność ta z kolei zwiększa tolerancję na zmianę społeczną i możliwości przystosowawcze jednostek do konkretnych rozwiązań nowego ustroju ekonomicznego, w szczególności do szeroko pojętego rynku³.

Jednocześnie należy zauważyć, że postawy pragmatyczne stoją w opozycji do postaw wrażliwości społecznej. Pojawia się wówczas pytanie, czy w nowej rzeczywistości ustrojowej jest miejsce na troskę o wspólny interes całej społeczności? Jak zauważa W. Zaborowski, w euforii głoszenia indywidualistycznie zorganizowanych zasad współzawodnictwa rynkowego i prywatnego władania środkami wytwórczości, kwestia interesu wspólnego stała się niewygodna czy wręcz szkodliwa4. Wymaga ona bowiem aktywizacji społecznej solidarności, zainteresowania innymi ludźmi oraz okazywania im współczucia. Swoistego rodzaju „stępienie” wrażliwości społecznej staje się problemem akcentowanym szczególnie wyraźnie w obszarze nauk o wychowaniu.

Postawy pragmatyczne należą do kategorii postaw społecznych. Postawy (podobnie jak wartości) są subkategoriami systemu przekonań ${ }^{5}$. Przekonania identyfikowane są z posiadanymi przez ludzi informacjami o nich samych, środowisku fizycznym i społecznym, ideach, przepisach prawnych, ideologiach (obejmują wiedzę, wyobrażenia i posiadane przez jednostkę wierzenia na temat danego obiektu). Przekonania wyraziste uważa się za bezpośrednie determinanty postawy wobec obiektu (postawy wyrastają zazwyczaj z przekonań). Postawy pozytywne kształtują się wtedy, gdy większość przekonań kojarzy z obiektem cechy pożądane, postawy negatywne - kiedy dominują przekonania o cechach niepożądanych ${ }^{6}$. Chociaż zaznaczają się kontrowersje wokól sposobu definiowania postaw, najczęściej

2 A. Jawłowska, Kierunki zmiany ustrojowej i konsekwencje społeczne, [w:] Społeczeństwo w transformacji. Ekspertyzy i studia, red. A. Rychard, M. Federowicz, Warszawa 1993, s. 168-200.

${ }^{3}$ M. Jarymowicz, O godzeniu wody z ogniem: zwiazki kolektywizmu z indywidualizmem, [w:] Psychologia rozumienia zjawisk społecznych, red. B. Wojciszke, M. Jarymowicz, Warszawa 1999, s. 121-152; J. Reykowski, Kolektywizm i indywidualizm jako kategorie opisu zmian społecznych i mentalności, Przegląd Psychologiczny, 1992, t. 35, s. 147-171; tegoż, Psychologia polityczna, [w:] Psychologia. Podręcznik akademicki (t. 3), red. J. Strelau, Gdańsk 2000, s. 379-403.

${ }^{4}$ W. Zaborowski, Pozycja ekonomiczna, gotowość do akceptacji gruntownej zmiany społecznej a orientacje proegalitarne, [w:] Społeczeństwo w transformacji. Ekspertyzy i studia, red. A. Rychard, M. Federowicz, Warszawa 1993, s. 69-77.

${ }^{5}$ M. Rokeach, The nature of human values, New York 1973.

${ }^{6}$ I. Ajzen, Postawy a zachowanie, [w:] Encyklopedia Blackwella. Psychologia społeczna, red. A.S.R. Manstead, M. Hewstone, przekł. A. Bieniek i in., Warszawa 1996, s. 395-400; W. Wosińska, Psychologia życia społecznego, Gdańsk 2004. 
są one rozumiane jako trwała ocena - pozytywna lub negatywna - ludzi, obiektów materialnych, idei, poglądów i zachowań własnych oraz innych osób. Są one zatem efektywnym sposobem wartościowania. Wartościowanie może wyrażać się poprzez reakcje różnego rodzaju: afektywne, poznawcze lub behawioralne, w sposób werbalny i niewerbalny?

Postawy społeczne - oprócz uwarunkowań zewnętrznych (np. kulturowych czy ustrojowych) - mają swoją głębszą psychologiczną przyczynę. $Z$ jednej strony, $\mathrm{u}$ ich podłoża leżą cenione przez człowieka wartości ${ }^{8}, \mathrm{z}$ drugiej - znaczącą rolę odgrywają czynniki osobowościowe9. W kontekście postaw rozważano między innymi takie właściwości jednostki, jak: orientacja na dominację społeczną czy autorytaryzm ${ }^{10}$. Na przykład, J. Koralewicz realizując badania $\mathrm{w}$ okresie przemian ustrojowych $\mathrm{w}$ Polsce stwierdziła, że osoby autorytarne $\mathrm{w}$ większym stopniu opierały się reformom, dążąc do wzmocnienia ówczesnych instytucji i ugruntowania pozycji przywódców ${ }^{11}$.

W niniejszej pracy przedstawione są wyniki badań odnoszące się do związku między postawami wrażliwości społecznej, opozycyjnymi wobec nich postawami pragmatycznymi a takimi cechami osobowości, jak empatia i makiawelizm. Cechy są hipotetycznymi, podstawowymi składnikami osobowości. Stanowią trwałą charakterystykę osoby, która służy do wyjaśnienia obserwowanych regularności i spójności zachowań oraz różnic między ludźmi ${ }^{12}$. Sformułowanie hipotez co do mających wystąpić zależności wymaga charakterystyki wskazanych cech osobowości.

7 A.H. Eagly, S. Chaiken, The psychology of attitudes, TX 1993; J.M. Olson, M.P. Zanna, Attitudes and attitude change, Annual Review of Psychology, 1993, 44, s. 117-154; A.S.R. Manstead, Teoria i badanie postaw, [w:] Encyklopedia Blackwella, s. 641-646; R.J. Gerrig, P.G. Zimbardo, Psychologia i życie, przekł. J. Radzicki i in., Warszawa 2009; por. także M. Czerniawska, Zmiany wartości i postaw młodzieży w okresie przeobrażeń ustrojowych.

8 S. Feldman, Wartości, ideologia i strukturalizacja postaw politycznych, [w:] Psychologia polityczna, red. D.O. Sears, L. Huddy, R. Jervis, przekł. R. Andruszko, Kraków 2008, s. 435-464.

9 A. Furnham, P. Heaven, Личность и соииальное поведение, Петер 2001.

${ }_{10}$ M. Mitchell, J. Sidanius, Group status and ideological asymmetry: The case of capital punishment, political conservatism and social dominance orientation, National Journal of Sociology, 1993, 7, s. 69-93; S. Stack, Authoritarianism and support for the death penalty: A multivariate Analysis, Sociological Focus, 2003, 36, s. 333-352; J. Sidanius i in., Support for harsh criminal sanctions and criminal justice beliefs: A social dominance perspective, Social Justice Research, 2006, 19, s. 433-449, T. Adorno, za: M.B. Smith, Авторитарная личность: переосмысление 46 лет сnустя, [w:] Политическая психология: Хрестоматия, red. Е.Б. Шестопал, Аспект Пресс, М. 2007, s. 285-290.

${ }^{11} \mathrm{~J}$. Koralewicz, Autorytaryzm a poglady polityczne Polaków, [w:] Orientacje spoteczne jako element mentalności, red. J. Reykowski, K. Skarżyńska, M. Ziółkowski, Poznań 1990, s. 77-92.

12 A.S. Reber, E.S. Reber, Stownik psychologii, przekł. B. Janasiewicz-Kruszyńska i in., Warszawa 2005. 
Empatię interpretuje się jako konstrukt multidymensjalny w swojej naturze, zawierający zarówno komponenty emocjonalne, jak i poznawcze ${ }^{13}$. Komponenty emocjonalne wyrażają się w empatycznej trosce (współczuciu), która doprowadza do koncentracji na nieszczęściu drugiej osoby i prób przywrócenia jej pomyślności, oraz - w osobistej przykrości (dyskomforcie), która z kolei zorientowana jest na Ja i przyniesienie ulgi we własnym cierpieniu. Komponent poznawczy empatii - przyjęcie perspektywy - odnosi się do zdolności widzenia świata oczyma innej osoby, wyobrażenia, co ona odczuwa $\mathrm{w}$ określonej sytuacji ${ }^{14}$. Badania nad prospołecznością doprowadziły do sformułowania „hipotezy altruizmu płynącego z empatii”. U osób empatycznych zwiększa się prawdopodobieństwo niesienia pomocy (pomoc ta jest bezinteresowna, motywowana troską o dobro drugiego człowieka, „bardziej delikatna i mniej kapryśna”), ograniczenia agresji i innych aspołecznych zachowań oraz wzrostu współpracy w sytuacjach konfliktowych ${ }^{15}$. Ludzie empatyczni są bardziej taktowni, lepiej komunikują się z innymi, przejawiają tolerancję do odmiennych grup społecznych, pozytywniej postrzegają innych i wyrażają sympatię do otoczenia społecznego ${ }^{16}$. Empatia rozpatrywana jest $\mathrm{w}$ kontekście zasad moralnych, jakimi są troska i sprawiedliwość oraz analizowana w procesie rozwoju moralnego ${ }^{17}$.

Termin „makiawelizm” stał się synonimem przebiegłości, oszustwa, fałszu i dwulicowości. Makiaweliści wierzą, że innymi należy manipulować

${ }_{13}$ M.H. Davis, Empathic concern and the muscular dystrophy telethon: Empathy as multidimensional construct, Personality and Social Psychology Bulletin, 1983, 9, s. 223-229; M.L. Hoffman, Interaction of affect and cognition in empathy, [w:] Emotions, cognition, and behavior, red. C.E. Izard, J. Kagan, R.B. Zajonc, Cambridge 1984, s. 103-131; N. Eisenberg, P.A. Miller, The relation of empathy to prosocial and related behavior, Psychological Bulletin, 1987, 101, s. 91-119; C.D. Batson, The altruism question: toward a social-psychological answer, NJ, Hillsdale 1991: por. także M. Czerniawska, Empatia a system wartości, Przegląd Psychologiczny, 2002, 45, s. 7-18.

14 C.D. Batson, The altruism question; N. Eisenberg, R.A. Fabes, Emotion, regulation, and the development of social competence, [w:] Review of personality and social psychology: Emotion and social behavior, red. M.S. Clark, Sage, CA 1992, s. 119-150; N. Eisenberg et al., The relations of emotionality and regulation to dispositional and situational empathy-related responding, Journal of Personality and Social Psychology, 1994, 66, s. 776-797; M.H. Davis, C. Luce, S.J. Kraus, The heritability of characteristics associated with dispositional empathy, Journal of Personality, 1994, 62, s. 369-391; M.D. Davis et al., Empathy, expectations, and situational preferences: Personality influences on the decision to participate in volunteer helping behaviors, Journal of Personality, 1999, 67, s. 469-501; K.P. Leith, R.F. Baumeister, Empathy, shame, guilt, and narratives of interpersonal conflicts: Guiltprone people are better at perspective taking, Journal of Personality, 1998, 66, s. 1-37.

${ }_{15}$ C.D. Batson, N. Ahmad, E.L. Stocks, Korzyści i problemy zwiazane z altruizmem wzbudzonym przez empatie, [w:] Dobro i zło z perspektywy psychologii społecznej, red. A.G. Miller, przekł. V. Reder, Kraków 2008, s. 447-479.

${ }_{16}$ M.H. Davis, Empatia. O umiejętności wspótodczuwania, przekł. J. Kubiak, Gdańsk 1999.

${ }_{17}$ M.L. Hoffman, Empatia i rozwój moralny, przekł. O. Waśkiewicz, Gdańsk 2006. 
i wierzą $w$ efekty takich zabiegów ${ }^{18}$. Są ukierunkowani przede wszystkim na sukces ${ }^{19}$ - sukces, który pozwala zdobyć prestiż i zaprezentować narcystyczną wspaniałość, przejawiającą się wyższością i arogancją. Osiągnięcia są rozpatrywane głównie $\mathrm{w}$ wymiarze indywidualnym (rodzina czy grupa nie stanowi centrum psychologicznego pola) i w kategoriach materialnych ${ }^{20}$. Makiawelizm związany jest $\mathrm{z}$ dążeniem do władzy i ukazania siły ${ }^{21}$ oraz potrzebą dominacji i kontroli22. Specyfika tego typu osobowości odzwierciedla się w sferze afektywnej. Relacje interpersonalne nie wywołują adekwatnych, pod względem treści i natężenia, emocji. Rzadkość stanowią emocje pozytywne, natomiast dominująca jest obojętność, czy wręcz chłód emocjonalny ${ }^{23}$. Makiaweliści nie są zorientowani wspólnotowo i utrzymują zdystansowaną postawę wobec innych. Ich "gruboskórność" manifestuje się $\mathrm{w}$ obniżonych zdolnościach empatycznych i nieumiejętności przyjęcia cudzej perspektywy. Inni ludzie są percypowani w sposób podejrzliwy i cyniczny, jako słabi, niegodni zaufania i skłonni do zdrady24. Ujawnia się wśród makiawelistów obojętność $\mathrm{w}$ myśleniu i działaniu w stosunku do konwencjonalnej moralności, co sprzyja łamaniu panujących norm. Wartości moralne realizowane są przez nich w sposób wybiórczy, o ile nie kolidują one z własnym interesem. Dążenie do sukcesu odgrywa pierwszoplanową rolę, zaś kwestia sposobów osiągania celów wydaje się nie mieć większego znaczenia ${ }^{25}$. Obraz świata społecznego jest cyniczny i obwarowany wysoce pragmatycznymi przekonaniami ${ }^{26}$.

18 B. Fehr, D. Samsom, D.L. Paulhus, The construct of Machiavellianism. Twenty years later, [w:] Advances in personality assessment (t. 9), red. C.D. Spielberger, J.N. Butcher, New York 1992, s. 77-116; D.S. Wilson, D. Near, R.R. Miller, Machiavellianism: A synthesis of evolutionary and psychological literatures, Psychological Bulletin, 1996, 119, s. 285-299; por. także M. Czerniawska, E. Dolata, Makiaweliści - dlaczego "prawie zawsze zwyciężaja”? Psychologia Rozwojowa, 2004, 9, s. $105-118$.

${ }^{19}$ R. Drwal, P. Brzozowski, Skala Makiawelizmu (Mach V) R. Christiego i F. L. Geis; problemy rzetelności i trafności, [w:] Adaptacja kwestionariuszy osobowości, red. R.Ł. Drwal, Warszawa 1995, s. 184-196.

${ }^{20}$ J.W. McHoskey, W. Worzel, C. Szyarto, Machiavellianism and psychopathy, Journal of Personality and Social Psychology, 1998, 74, s. 192-210.

${ }^{21}$ J.A. Shepperd, R.E. Socherman, On the manipulative behavior of low Machiavellians: Feigning incompetence to "sandbag" an opponent's effort, Journal of Personality and Social Psychology, 1997, 72, s. 1448-1459.

22 J.S. Wiggins, R. Broughton, The interpersonal circle: A structural model for the integration of personality research, [w:] Perspectives in personality (t. 1), red. R. Hogan, W.H. Jones, CT 1985, s. 1-47.

23 Tamże.

${ }^{24}$ B. Fehr, D. Samsom, D.L. Paulhus, The construct of Machiavellianism, s. 77-116; D.S. Wilson, D. Near, R.R. Miller, Machiavellianism: A synthesis of evolutionary, s. 285-299.

25 B. Fehr, D. Samsom, D.L. Paulhus, The construct of Machiavellianism, s. 77-116.

${ }^{26}$ R. Christe, F.L. Geis, za: J.F. Rauthmann, T. Will, Proposing a multidimensional Machiavellianism conceptualization, Social Behavior and Personality, 2011, 39, s. 391-404. 


\section{Problem badawczy i hipotezy}

W prezentowanym badaniu podjęto próbę odpowiedzi na pytanie, czy postawy pragmatyczne versus postawy wrażliwości społecznej można rozpatrywać w kontekście cech osobowościowych, jakimi są empatia i makiawelizm?

Powyżej przedstawiona została charakterystyka dwóch cech osobowości. Jak można zauważyć, odgrywają one rolę w określeniu relacji Ja - Inni. Empatia leży u podłoża konstruowania dojrzałych relacji międzyludzkich i generowania pozytywnych intencji behawioralnych. Skłania do zachowań prospołecznych, mających ma celu dobrostan innych ludzi, oraz powstrzymywania zachowań antyspołecznych, wymierzonych przeciwko otoczeniu. Osoby empatyczne skłonne są zatem do przyjęcia allocentrycznej perspektywy w analizie zjawisk społecznych. Częściej też wierzą w dobroć człowieka. W przypadku makiawelizmu typowa jest koncentracja na własnej osobie, skłonność do realizacji osobistych interesów, z pominięciem dobrostanu innych ludzi, a nawet wbrew ich dobru. Osoby makiawelistyczne mają problemy z porzuceniem egocentrycznej perspektywy, zaś inni ludzie są percypowani w negatywny sposób, jako ci którzy nie stanowią wartości "sami w sobie". Ponadto, jednym z elementów opisu osobowości makiawelistycznej jest właśnie pragmatyzm.

Uwzględniając powyższą charakterystykę założono, że postawy wrażliwości społecznej ujawniają się wśród studentów uzyskujących wyższe wskaźniki empatii (hipoteza 1), z kolei postawy przeciwstawne, tj. pragmatyczne - wśród studentów cechujących się wyższymi wskaźnikami makiawelizmu (hipoteza 2).

\section{Metoda}

Grupa badana. W badaniach wzięło udział 325 osób: około $50 \%$ uczestników było studentami pedagogiki, około $50 \%$ - studentami zarządzania. Wiek badanych mieścił się w przedziale 20-24 lata. W obu grupach stwierdzono analogiczną proporcję płci: na wskazanych kierunkach studiów zarejestrowano przewagę liczbową kobiet. Badanie miało charakter anonimowy.

Procedura badawcza. W niniejszej pracy postawy były diagnozowane za pomocą par twierdzeń, które stanowią alternatywne przekonania. Twierdzenia te są zmodyfikowaną treściowo wersją narzędzia zamieszczonego 
w pracy pod redakcją Janusza Reykowskiego Wartości i postawy Polaków a zmiany systemowe27.

\section{POSTAWA A}

1. Tym, co się liczy nadal jest to, jakim kto jest człowiekiem i co się dzieje między ludźmi, a nie to, ile kto ma pieniędzy. Życie nie polega tylko na bogaceniu się.

2. Minęła już epoka, kiedy pracowaliśmy dla „idei”. Nastąpił czas dla ludzi myślących praktycznie i potrafiących radzić sobie w życiu - również ekonomicznie.

\section{POSTAWA B}

1. Obywatelskie zaangażowanie społeczne jest konieczne dla poprawy warunków życia naszej społeczności i całego kraju.

2. Tak zwana "postawa społecznego zaangażowania dla dobra ogółu” to slogan minionej epoki. Wszystkim będzie lepiej, jeżeli każdy zajmie się swoimi sprawami i swoimi pieniędzmi.

Zadaniem osób badanych była ocena tych poglądów i wybór jednej $\mathrm{z}$ dwóch opcji, tej, która $\mathrm{w}$ większym stopniu odzwierciedla przekonania jednostki odnośnie do analizowanego problemu.

Cechy osobowości diagnozowano za pomocą:

- empatia - Kwestionariusz Rozumienia Empatycznego Innych Ludzi A. Węglińskiego ${ }^{28}$. Wskaźniki zawierają się w przedziale od 0 do 99 punktów;

- makiawelizm - Skala Mach V.R. Christiego i F.L. Geis ${ }^{29}$. Wskaźniki zawierają się w przedziale od 40 do 160 punktów.

\section{Wyniki}

W niniejszym badaniu starano się ustalić, czy postawy wrażliwości społecznej (orientacja na jakość kontaktów międzyludzkich i realizacja „dobra wspólnego") oraz postawy pragmatyczne (orientacja na realizację własnych

\footnotetext{
${ }^{27}$ J. Reykowski (red.), Wartości i postawy Polaków a zmiany systemowe. Szkice z psychologii politycznej, Warszawa 1993.

28 A. Węgliński, Trafność Kwestionariusza Rozumienia Empatycznego Innych Ludzi, [w:] Techniki kwestionariuszowe w diagnostyce psychologicznej, red. R. Drwal, Lublin 1987, s. 63-80.

${ }^{29}$ R. Drwal, P. Brzozowski, Skala Makiawelizmu (Mach V) R. Christiego i F.L. Geis, s. 184-196.
} 
interesów i zaspokojenie własnych potrzeb) uzależnione są od takich cech osobowości, jak empatia i makiawelizm?

Tabela 1

Postawy wrażliwości społecznej versus postawy pragmatyczne a cechy osobowości

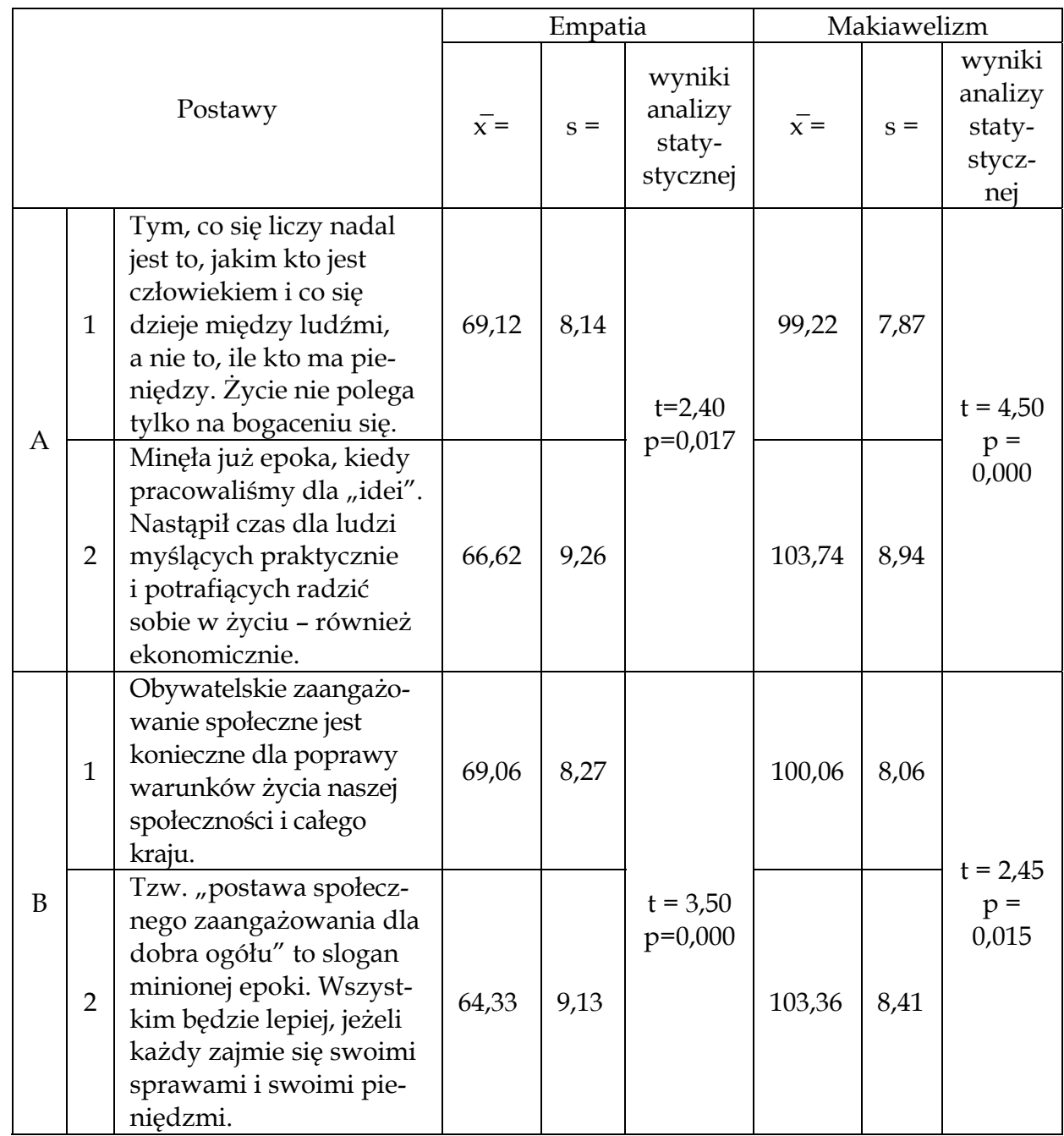

$\bar{x}$ - średnia arytmetyczna wskaźników cech osobowości,

$\mathrm{s}$ - odchylenie standardowe,

$\mathrm{t}$ - wynik testu $\mathrm{t}$ Studenta,

$\mathrm{p}$ - poziom istotności statystycznej.

Źródło: badania własne. 
Postawy, w których pozytywnie ocenia się wrażliwość społeczną, "człowieczeństwo", jakość relacji międzyludzkich i zaangażowanie jednostki w ważną - z punktu widzenia dobra wspólnego - aktywność charakteryzują studentów uzyskujących wyższe wskaźniki empatii i niższe wskaźniki makiawelizmu. Postawy pragmatyczne wiązały się z kolei ze stosunkowo wyższymi wskaźnikami makiawelizmu i niższymi wskaźnikami empatii. Ich efektem jest aprobata przedsiębiorczości i skłonność do realizacji własnych interesów ekonomicznych: w życiu trzeba przede wszystkim skupiać się na walce o swoje sprawy, nie zważając na innych ludzi. Wyniki analizy zamieszczone $\mathrm{w}$ tabeli 1 wskazują, że różnice we wskaźnikach empatii i makiawelizmu w zależności od wyboru opcji w postawie A i B są istotne statystycznie. Jest to podstawa do przyjęcia założeń zwerbalizowanych w hipotezie 1 i 2.

\section{Podsumowanie}

A. Jawłowska wskazuje na relatywny wzrost pragmatyzmu w okresie transformacji ustrojowej w krajach Europy Środkowej i Wschodniej ${ }^{30}$. Warunkował on zmiany $\mathrm{w}$ sferze ekonomicznej i ułatwiał przystosowanie do nowych warunków. Stanowił - najogólniej rzecz ujmując - psychologiczną reakcję na wprowadzenie gospodarki rynkowej. Nasilenie pragmatyzmu mogło być spowodowane obiektywnym spadkiem poziomu życia oraz wzrostem ekonomicznego zróżnicowania (pojawienie się ludzi bardzo bogatych i bardzo biednych), jak również większą widocznością tego zróżnicowania przez ostentacyjną konsumpcję. Legalizuje się wówczas orientacja na potrzeby materialne, pomyślność i dobrobyt. Postawy pragmatyczne można uznać za wskaźnik zmian mentalności w kierunku indywidualizmu, jako że sprzyjają one racjonalności, praktycznemu podejściu do życia, skuteczności w nabywaniu kompetencji i skłonności do rozpatrywania problemów z punktu widzenia osobistych osiągnięć i sukcesów, a nie z punktu widzenia dobra wspólnoty ${ }^{31}$. Niemniej jednak, nadmierny pragmatyzm doprowadza do rozbicia spójności społeczeństwa, osłabienia tradycjonalizmu w sferze kulturowej i religijnej, zaniku solidarności oraz instrumentalnego traktowa-

30 A. Jawłowska, Kierunki zmiany ustrojowej, s. 168-200.

31 T. Bodio, Psychologiczne uwarunkowania transformacji ustrojowej, [w:] Społeczeństwo i polityka. Podstawy nauk politycznych, red. K.A. Wojtaszczyk, W. Jakubowski, Warszawa 2003, s. 877-890. 
nia ludzi ${ }^{32}$. Ta ciemna strona pragmatyzmu akcentowana jest zwłaszcza przez przedstawicieli nauk o wychowaniu ${ }^{33}$. Człowiek pragmatyczny "trzyma się ziemi", unika analizy zdarzeń w szerszej perspektywie społecznej, zaś koncentracja na sobie dewaluuje znaczenie harmonijnych relacji między ludźmi. To z kolei utrudnia funkcjonowanie ludzi zgodnie $\mathrm{z}$ wymogami dojrzałej demokracji, w której powinna manifestować się troska obywateli o dobro w sferze publicznej. Pragmatyzm sprzyja raczej budowie "kapitału ekonomicznego", związanego z produkcją i konsumpcją dóbr, niż „kapitału społecznego", w postaci więzi, zaufania, prospołeczności i zaangażowania obywatelskiego. W aspekcie socjalizacyjnym ważne wydaje się określenie pożądanych proporcji między wagą obu rodzajów kapitału - tak, aby umieć radzić sobie w życiu, ale nie stracić z oczu "dobra wspólnego". Możliwe jest to - jak wskazuje A. Radziewicz-Winnicki - poprzez rozwój świadomości politycznej, rozwijanie krytycznego myślenia, kształtowanie postaw i wartości oraz promowanie aktywnej partycypacji ${ }^{34}$.

Nie do podważenia jest fakt, że pragmatyzm wzmaga się $\mathrm{w}$ czasach szybkich zmian ustrojowych i postawy go aprobujące kształtują się w tym szczególnym kontekście. Niemniej jednak ludzie różnią się pod względem jego natężenia. $\mathrm{W}$ związku $\mathrm{z}$ tym istotne wydaje się pytanie, od jakich jeszcze czynników uzależniona jest akceptacja pragmatycznego podejścia do życia? W prezentowanym badaniu zwrócono uwagę na dwie cechy osobowości - empatię i makiawelizm - które $\mathrm{z}$ teoretycznego punktu widzenia powinny warunkować postawy wrażliwości społecznej i postawy, które są ich przeciwieństwem, to jest pragmatyczne.

Okazało się, że ludzie o osobowości empatycznej promują wrażliwość społeczną, dobro wspólne i solidaryzm społeczny. Optują zatem za bardziej tradycyjną strukturą społeczną. Ludzie o osobowości makiawelistycznej promują z kolei nastawienie pragmatyczne, w którym absolutyzowany jest interes jednostkowy. Ujawnia się wówczas bardziej indywidualny stosunek do otoczenia społecznego, orientacja na cele osobiste i dobro własne, lekceważone są potrzeby społeczności i tzw. dobro ogółu, a nawet - w skrajnej sytuacji - pomijane problemy sprawiedliwości i moralności. Zgodne jest to

32 Por. także M. Czerniawska, Zmiany wartości i postaw młodzieży w okresie przeobrażeń ustrojowych.

${ }^{33}$ M. Dudzikowa, Erozja kapitału społecznego w szkole w kulturze nieufności, [w:] Wychowanie. Pojęcia, procesy, konteksty, red. M. Dudzikowa, M. Czerepniak-Walczak, Gdańsk 2008, s. 205262; A. Radziewicz-Winnicki, Pedagogika społeczna, Warszawa 2008; E. Potulicka, Edukacja dla demokracji, [w:] Przemiany wartości $i$ stylów życia w ponowoczesności, red. J. Dyszkowska, M. Rewera, Warszawa 2010, s. 83-104.

${ }^{34}$ A. Radziewicz-Winnicki, Pedagogika spoteczna. 
z sugestią C. Lasha, iż narcystycznie zapatrzony w siebie człowiek (narcyzm jest cechą makiawelistów - por. charakterystykę przedstawioną powyżej) nie jest w stanie wytworzyć światopoglądu, który wykraczałby poza miłość własnego $\mathrm{Ja}^{35}$. Dane empiryczne analizowane w niniejszym badaniu wskazują, że cechy osobowości stanowią jeden z czynników warunkujących kształtowanie postaw społecznych. Nie wyjaśniają jednak, czy cechy te wpływają na postawy bezpośrednio. Skłania to do bardziej ogólnych rozważań teoretycznych na temat związku między osobowościową a postawami, to jest jego przyczynowością (który konstrukt determinuje, a który jest determinowany) i bezpośredniością (czy są mediatory związku między osobowością a postawami).

Cechy osobowości mają często biologiczne podstawy (zestaw wrodzonych predyspozycji) i charakteryzują się w związku z tym dużą stabilnością. Postawy są również stabilne (chociaż zwykle nie w takim stopniu), ale kształtują się w późniejszym okresie życia niż cechy osobowości36 i wymagają względnie bogatych doświadczeń społecznych. Z uwagi na pierwotność cech osobowości przyjmuje się, że są one jednym (chociaż nie jedynym) determinantem postaw. Ludzie "starają się" dostosować postawy do posiadanych cech osobowości. Jednak fakt, że biologiczne cechy ukierunkowują kształtowanie postaw nie oznacza, że postawy są niezależne od wpływów społecznych (m.in. środowiska rodzinnego, szkolnego, rówieśniczego, mediów). Co więcej, postawy mogą przyczynić się do modyfikacji osobowości. W literaturze przedmiotu podejmowane są też inne próby wyjaśnienia relacji między osobowością a postawami społecznymi. Na przykład, C. Kandler i inni oraz P.K. Verhulst i inni podważyli przyczynowy związek między obydwoma konstruktami i wskazali na uwarunkowania genetyczne: geny leżą u podstaw kształtowania zarówno osobowości, jak i postaw, co ujawnia się już w okresie wczesnego dzieciństwa ${ }^{37}$. Dokonując analizy relacji między osobowością a postawami należy zwrócić uwagę na fakt, że funkcjonowanie człowieka stanowi pewną psychologiczną całość i, jak zauważa L.A. Pervin,

35 T. Biernat, Społeczno-kulturowe uwarunkowania światopoglądu młodzieży w okresie transformacji, Toruń 2006.

36 A. Blais, S. Labbé St-Vincent, Personality traits, political attitudes and the propensity to vote, European Journal of Political Research, 2011, 50, s. 395-417.

37 C. Kandler, W. Bleidorn, R. Riemann, Left or right? Sources of political orientation: The roles of genetic factors, cultural transmission, assortative mating, and personality, Journal of Personality and Social Psychology, 2012, 102, s. 633-645; B. Verhulst, P.K. Hatemi, N.G. Martin, The nature of the relationship between personality traits and political attitudes, Personality and Individual Differences, 2010, 49, s. 306-316. 
różne elementy dotyczące własnej osoby muszą wejść ze sobą w relacje na poziomie tworzenia $\mathrm{Ja}^{38}$.

A. Van Hiel i współautorzy koncentrowali się z kolei na mediatorach relacji między osobowością a postawami społecznymi. Wyeksponowali znaczenie ludzkich poglądów na świat społeczny (ludzi, grupy społeczne i stosunki między nimi), przy czym poglądy te - $\mathrm{w}$ ujęciu psychologicznym stanowią schemat poznawczy ważny $\mathrm{w}$ samookreśleniu jednostki i chronicznie dostępny (będący w stałej gotowości do wykorzystania). Założyli, że cechy osobowościowe (mające biologiczne podłoże, tak jak w przypadku Wielkiej Piątki) predysponują $\mathrm{w}$ trakcie socjalizacji do przyjęcia określonego poglądu na świat, który z kolei wpływa na postawy społeczne. Analiza statystyczna obejmowała relacje między wieloma zmiennymi, co uniemożliwia przytoczenie szczegółowych wyników. Ogólny - i siłą rzeczy uproszczony wniosek z tych badań sformułować można w następujący sposób: pogląd na świat społeczny - jego treść - jest mediatorem związków między osobowością a społecznymi postawami ${ }^{39}$.

Model A. Van Hiela i współpracowników można zastosować do wyjaśnienia zależności uzyskanych $\mathrm{w}$ relacjonowanym badaniu własnym. Należy zaznaczyć, że pogląd na świat rozumiany jest jako głęboko zakorzenione przekonania, wiara jednostki na temat ludzkiej natury i świata społecznego: na ile ten świat jest przyjazny, a na ile wrogi, jacy są inni ludzie, jakich zachowań $\mathrm{z}$ ich strony należy się spodziewać $\mathrm{i}$ jak powinno się na nie reagować (Rokeach oraz Duckitt, Fisher) ${ }^{40}$. Przekonanie, że świat społeczny jest miejscem współpracy i harmonii (jest bardziej prawdopodobne, że taka wizja świata zrodzi się w umysłach osób cechujących się empatią) stymuluje postawy wrażliwości społecznej, skłonność do dzielenia się dobrami i działania na korzyść innych ludzi. Przekonanie, że rywalizacja jest wpisana w życie społeczne i warunkuje cel egzystencji, jakim jest osobisty dobrostan (typowe $\mathrm{w}$ przypadku makiawelistów), stymuluje $\mathrm{z}$ kolei pragmatyczny stosunek do życia.

\section{BIBLIOGRAFIA}

Ajzen I., Postawy a zachowanie, [w:] Encyklopedia Blackwella. Psychologia społeczna, red. A.S.R. Manstead, M. Hewstone, przekł. A. Bieniek i in., Wydawnictwo Jacek Santorski \& CO, Warszawa 1996.

${ }^{38}$ L.A. Pervin, Psychologia osobowości, przekł. M. Orski, Gdańsk 2002.

39 A. Van Hiel, I. Cornelis, A. Roets, The Intervening role of social worldviews in the relationship between the five-factor model of personality and social attitudes, European Journal of Personality, 2007, 21, s. 131-148.

40 Tamże. 
Batson C.D., The altruism question: toward a social-psychological answer, Lawrence Erlbaum Associates, NJ, Hillsdale 1991.

Batson C.D., Ahmad N., Stocks E.L., Korzyści i problemy związane z altruizmem wzbudzonym przez empatie, [w:] Dobro i zło z perspektywy psychologii społecznej, red. A.G. Miller, przekł. V. Reder, Wydawnictwo WAM, Kraków 2008.

Biernat T., Społeczno-kulturowe uwarunkowania światopogląu młodzieży w okresie transformacji, UMK, Torun 2006.

Blais A., Labbé St-Vincent S., Personality traits, political attitudes and the propensity to vote, European Journal of Political Research, 2011, 50.

Bodio T., Psychologiczne uwarunkowania transformacji ustrojowej, [w:] Społeczeństwo i polityka. Podstawy nauk politycznych, red. K.A. Wojtaszczyk, W. Jakubowski, Oficyna Wydawnicza ASPRA-JR, Warszawa 2003.

Czerniawska M., Empatia a system wartości, Przegląd Psychologiczny, 2002, 45.

Czerniawska M., Zmiany wartości i postaw młodzieży w okresie przeobrażeń ustrojowych kolektywizm versus indywidualizm. Studium interdyscyplinarne, Wydawnictwo Politechniki Białostockiej, Białystok 2010.

Czerniawska M., Dolata E., Makiaweliści - dlaczego "prawie zawsze zwyciężają"? Psychologia Rozwojowa, 2004, 9.

Davis M.H., Empathic concern and the muscular dystrophy telethon: Empathy as multidimensional construct, Personality and Social Psychology Bulletin, 1983, 9.

Davis M.H., Empatia. O umiejętności wspótodczuwania, przekł. J. Kubiak, Gdańskie Wydawnictwo Psychologiczne, Gdańsk 1999.

Davis M.H., Luce C., Kraus S.J., The heritability of characteristics associated with dispositional empathy, Journal of Personality, 1994, 62.

Davis M.D., Mitchell K.V., Hall J.A., Lothert J., Snapp T., Meyer M., Empathy, expectations, and situational preferences: Personality influences on the decision to participate in volunteer helping behaviors, Journal of Personality, 1999, 67.

Drwal R., Brzozowski P., Skala Makiawelizmu (Mach V) R. Christiego i F.L. Geis; problemy rzetelności i trafności, [w:] Adaptacja kwestionariuszy osobowości, red. R.Ł. Drwal, PWN, Warszawa 1995.

Dudzikowa M., Erozja kapitału społecznego w szkole w kulturze nieufności, [w:] Wychowanie. Pojęcia, procesy, konteksty, red. M. Dudzikowa, M. Czerepniak-Walczak, Gdańskie Wydawnictwo Psychologiczne, Gdańsk 2008.

Eagly A.H., Chaiken S., The psychology of attitudes, Harcourt Brace Jovanovich, Fort Worth, TX 1993.

Eisenberg N., Fabes R.A., Emotion, regulation, and the development of social competence, [w:] Review of personality and social psychology: Emotion and social behavior, red. M.S. Clark, Sage, Newbury Park, CA 1992.

Eisenberg N., Fabes R.A., Murphy B., Karbon M., Maszk P., Smith M., O’Boyle C., Suh K., The relations of emotionality and regulation to dispositional and situational empathy-related responding, Journal of Personality and Social Psychology, 1994, 66.

Eisenberg N., Miller P.A., The relation of empathy to prosocial and related behavior, Psychological Bulletin, 1987, 101.

Fehr B., Samsom D., Paulhus D.L., The construct of Machiavellianism. Twenty years later, [w:] Advances in personality assessment (t. 9), red. C.D. Spielberger, J.N. Butcher, Erlbaum, Hillsdale, NJ 1992. 
Feldman S., Wartości, ideologia i strukturalizacja postaw politycznych, [w:] Psychologia polityczna, red. D.O. Sears, L. Huddy, R. Jervis, przekł. R. Andruszko, Wydawnictwo Uniwersytetu Jagiellońskiego, Kraków 2008.

Furnham A., Heaven P., Личность и социальное поведение, СПб.: Петер 2001.

Gerrig R.J., Zimbardo P.G., Psychologia $i \dot{z} y c i e$, przekł. J. Radzicki i in., Wydawnictwo Naukowe PWN, Warszawa 2009.

Hoffman M.L., Interaction of affect and cognition in empathy, [w:] Emotions, cognition, and behavior, red. C.E. Izard, J. Kagan, R.B. Zajonc, Cambridge University Press, Cambridge 1984 .

Hoffman M.L., Empatia i rozwój moralny, przekł. O. Waśkiewicz, Gdańskie Wydawnictwo Psychologiczne, Gdańsk 2006.

Jarymowicz M., O godzeniu wody z ogniem: zwiąki kolektywizmu z indywidualizmem, [w:] Psychologia rozumienia zjawisk spotecznych, red. B. Wojciszke, M. Jarymowicz, Wydawnictwo Naukowe PWN, Warszawa 1999.

Jawłowska A., Kierunki zmiany ustrojowej i konsekwencje społeczne, [w:] Społeczeństwo $w$ transformacji. Ekspertyzy $i$ studia, red. A. Rychard, M. Federowicz, Wydawnictwo IFiS PAN, Warszawa 1993.

Kandler C., Bleidorn W., Riemann R., Left or right? Sources of political orientation: The roles of genetic factors, cultural transmission, assortative mating, and personality, Journal of Personality and Social Psychology, 2012, 102.

Koralewicz J., Autorytaryzm a poglady polityczne Polaków, [w:] Orientacje społeczne jako element mentalności, red. J. Reykowski, K. Skarżyńska, M. Ziółkowski, Wydawnictwo Nakom, Poznań 1990.

Leith K.P., Baumeister R.F., Empathy, shame, guilt, and narratives of interpersonal conflicts: Guilt-prone people are better at perspective taking, Journal of Personality, 1998, 66.

Manstead A.S.R., Teoria i badanie postaw, [w:] Encyklopedia Blackwella. Psychologia społeczna, red. A.S.R. Manstead, M. Hewstone, Wydawnictwo Jacek Santorski \& CO, Warszawa 2001.

McHoskey J.W., Worzel W., Szyarto C., Machiavellianism and psychopathy, Journal of Personality and Social Psychology, 1998, 74.

Mitchell M., Sidanius J., Group status and ideological asymmetry: The case of capital punishment, political conservatism and social dominance orientation, National Journal of Sociology, 1993, 7 .

Olson J.M., Zanna M.P., Attitudes and attitude change, Annual Review of Psychology, 1993, 44.

Pervin L.A., Psychologia osobowości, przekł. M. Orski, Gdańskie Wydawnictwo Psychologiczne, Gdańsk 2002.

Potulicka E., Edukacja dla demokracji, [w:] Przemiany wartości i stylów życia w ponowoczesności, red. J .Dyszkowska, M. Rewera, Wydawnictwo Akademickie Żak, Warszawa 2010.

Radziewicz-Winnicki A., Pedagogika spoteczna, Wydawnictwa Akademickie i Profesjonalne, Warszawa 2008.

Rauthmann J.F., Will T., Proposing a multidimensional Machiavellianism conceptualization, Social Behavior and Personality, 2011, 39.

Reber A.S., Reber E.S., Stownik psychologii, przekł. B. Janasiewicz-Kruszyńska i in., Wydawnictwo Naukowe Scholar, Warszawa 2005.

Reykowski J., Kolektywizm i indywidualizm jako kategorie opisu zmian społecznych $i$ mentalności, Przegląd Psychologiczny, 1992, 35. 
Reykowski J. (red.), Wartości i postawy Polaków a zmiany systemowe. Szkice z psychologii politycznej, Wydawnictwo Instytutu Psychologii PAN, Warszawa 1993.

Reykowski J., Psychologia polityczna, [w:] Psychologia. Podręcznik akademicki (t. 3), red. J. Strelau, Gdańskie Wydawnictwo Psychologiczne, Gdańsk 2000.

Rokeach M., The nature of human values, Free Press, New York 1973.

Shepperd J.A., Socherman R.E., On the manipulative behavior of low Machiavellians: Feigning incompetence to "sandbag" an opponent's effort, Journal of Personality and Social Psychology, 1997, 72.

Sidanius J., Mitchell M., Haley H., Navarrete C.D., Support for harsh criminal sanctions and criminal justice beliefs: A social dominance perspective, Social Justice Research, 2006, 19.

Smith M.В., Авторитарная личность: переосмысление 46 лет спустя, [w:] Политическая психология: Хрестоматия, red. Е.Б. Шестопал, Аспект Пресс, М. 2007.

Stack S., Authoritarianism and support for the death penalty: A multivariate Analysis, Sociological Focus, 2003, 36.

Van Hiel A., Cornelis I., Roets A., The Intervening role of social worldviews in the relationship between the five-factor model of personality and social attitudes, European Journal of Personality, 2007, 21.

Verhulst B., Hatemi P.K., Martin N.G., The nature of the relationship between personality traits and political attitudes, Personality and Individual Differences, 2010, 49.

Węgliński A., Trafność Kwestionariusza Rozumienia Empatycznego Innych Ludzi, [w:] Techniki kwestionariuszowe w diagnostyce psychologicznej, red. R. Drwal, UMCS, Lublin 1987.

Wiggins J.S., Broughton R., The interpersonal circle: A structural model for the integration of personality research, [w:] Perspectives in personality (t. 1), red. R. Hogan, W.H. Jones, JAI Press, Greenwich, CT 1985.

Wilson D.S., Near D., Miller R.R., Machiavellianism: A synthesis of evolutionary and psychological literatures, Psychological Bulletin, 1996, 119.

Wosińska W., Psychologia życia społecznego, Gdańskie Wydawnictwo Psychologiczne, Gdańsk 2004.

Zaborowski W., Pozycja ekonomiczna, gotowość do akceptacji gruntownej zmiany społecznej a orientacje proegalitarne, [w:] Społeczeństwo w transformacji. Ekspertyzy i studia, red. A. Rychard, M. Federowicz, Wydawnictwo IFiS PAN, Warszawa 1993. 
